\title{
On the Occurrence of Intrafascicular Cambium in Monocotyledons.
}

\author{
BY \\ AGNES ARBER. \\ With three Figures in the Text. \\ INTRODUCTION.
}

\begin{abstract}
A $\mathrm{N}$ impression seems to prevail among botanists that the occurrence A of intrafascicular cambium in Monocotyledons is extremely rare, except perhaps in seedlings. It may therefore be worth while to collect together some of the scattered observations on this subject, which tend to show that an ephemeral cambium is, in reality, a widespread anatomical feature of this group, and also to record a few fresh examples and to figure and describe briefly a case in which the cambium can be particularly well observed.

I am indebted to Miss Saunders, Director of the Balfour Laboratory, for facilities for anatomical work, and to the Newnham College Fellowship Committee for a grant towards the expenses of this and other researches. I wish also to express my thanks to $\mathrm{Mr}$. Boodle, for his help in connexion with the literature, and to Mr. Lynch, of the Cambridge Botanic Garden, for his kindness in supplying me with material.
\end{abstract}

\section{REVIEW OF THE LITERATURE.}

The earliest observation on the occurrence of intrafascicular cambium in Monocotyledons appears to be that of Russow, ${ }^{1}$ who, in 1875 , described, in the vascular bundle of Hemerocallis fulva, 'eine Andeutung eines Cambiumstreifens'. This was followed in 1884 by Godfrin's ${ }^{2}$ record that in the veins of the cotyledon of Latania borbonica (Palmae) an active cambial zone occurred. Two years later Möbius ${ }^{3}$ observed traces of a cambium in the stems of Listera ovata and Orchis maculata, and found that Limodorum abortivum was distinguished by somewhat more prolonged cambial activity.

In 1888 the subject was placed on a much broader basis by Fröken Sigrid Andersson's ${ }^{4}$ researches, which, owing to their publication in

1 Russow, F. (1875).

3 Möbius, M. (1886).

2 Godfrin, J. (1884), p. 47 and Pl. III, Fig. 43.

4 Andersson, S. (1888).

[Annals of Botany, Vol. XXXI. No. CXXI. January, 19I7.] 
Swedish, have perhaps scarcely received the attention they deserve. This author found that intrafascicular cambium was extremely widespread in the young tissues of Monocotyledons, and that the development of the bundle in this group was, in this respect, not nearly so divergent from that in the Dicotyledons as had previously been supposed. Her work was not confined to seedlings, as some citations from it might seem to indicate. She figured the following cases, some of which showed a fair development of cambium, while in others merely a trace of meristematic activity occurred: Triglochin maritimum (stem), Cyperus alternifolius (leaf), Zea Mays (leafsheath and stem), Amomum sp. (stem), Typha sp. (leaf), Brahea filamentosa (petiole), Platanthera bifolia (stem), Allium senescens (leaf), A. mutans (leaf), Lilium Martagon (stem), L. candidum (stem), L. japonicum (stem), and Dracaena sp. (stem). She drew attention to the similarity of the bundles of Ranunculus repens and those of Lilium, and figured them side by side for comparison.

Ten years later Gravis ${ }^{1}$ recorded the occurrence of intrafascicular cambium in the stem and leaf of Tradescantia virginica. The cambium, which is extremely clear in the young stem bundle, leaves no trace when the adult state is reached.

In 1899 Queva ${ }^{2}$ described the most remarkable instance of intrafascicular cambial activity yet recorded for Monocotyledons. In Gloriosa superba tubers are formed and filled with starch in one season and depleted during the next year. The bundles thus pass through two periods of activity separated by a period of rest. In the second period of activity, xylem and phloem elements are formed from the cambium. This resumption of cambial activity, after an interval during which cell division has been in abeyance, is, so far as our present knowledge goes, unique among Monocotyledons.

T. G. Hill, ${ }^{3}$ in 1900 , rediscovered and figured the intrafascicular cambium of the stem of Triglochin maritimum-one of the cases which Andersson had described and illustrated at an earlier date.

The Cyperaceae and Gramineae-families in which Andersson had already recorded the existence of cambium-received further attention from this point of view in I906. Plowman ${ }^{4}$ noted, in this year, that he had observed evidence of cambial activity in the internodal bundles of practically all the examples of the Cyperaceae which he studied. In the same year Chrysler ${ }^{5}$ drew attention to its occurrence in the stem and leaves of more than twenty species of grasses. The development of cambium just above the nodes is associated by this author with the power, which the grasses possess, of bending upwards when the stem is laid horizontally.

1 Gravis, A. (1898).

${ }^{3}$ Hill, T. G. (1900), Pl. IV, Fig. 5 .

${ }^{5}$ Chrysler, M. A. (1906).
2 Queva, C. (1899).

4 Plowman, A. B. (1906). 
Two years later Miss Sargant ${ }^{1}$ added to the records already made by Fröken Andersson for the Liliaceae and Scitamineae, by describing cases of cambial development in certain seedlings belonging to these orders. She observed intrafascicular cambium in the hypocotyl of Yucca arborescens, $Y$. gloriosa, and $Y$. aloifolia, the cotyledonary bundles of Milla, Dipcadi, Galtonia, Albuca, and Fritillaria, and the plumular leaves of Elettaria and Musa.

\section{OBSERVATIONS.}

The bundles of the young inflorescence axis of Eremurus himalaicus, Baker, one of the Asphodelinae, show cambial activity very clearly. In an extremely young inflorescence axis, less than $5 \mathrm{~cm}$. long, dissected out of the

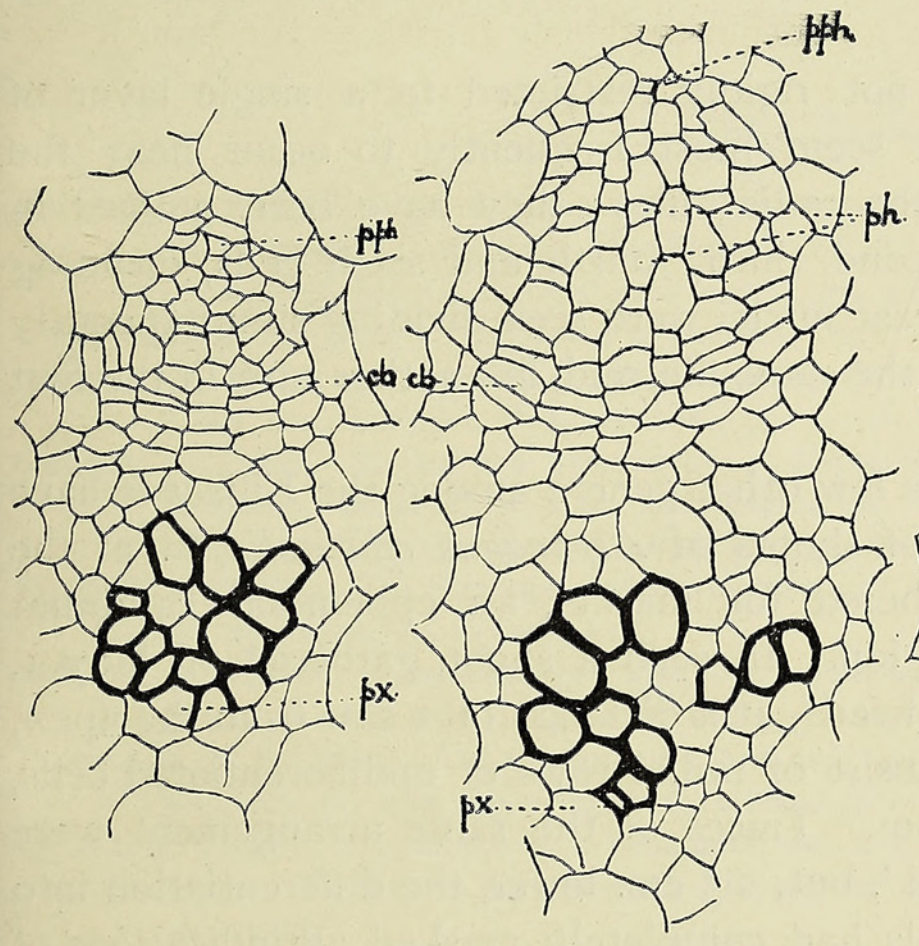

FIG. I.

FIG. 2.

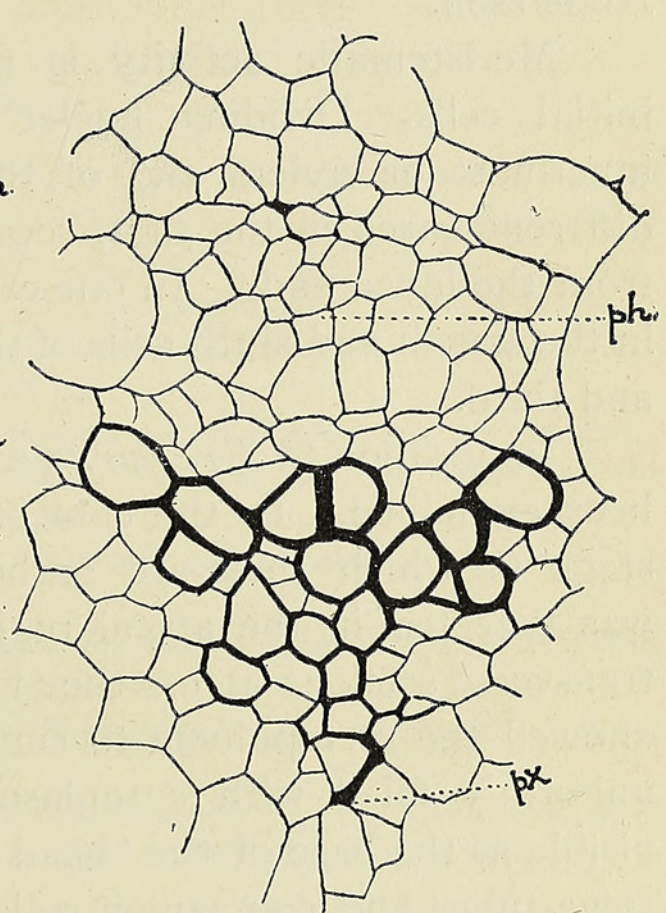

FIG. 3 .

Figs. I-3. Transverse sections of vascular bundles from inflorescence axes of Eremurus himalaicus, Baker. I. A bundle from the flowering region of an axis gathered May 7 , showing cambium. The phloem is not fully differentiated. 2. A bundle from the region below the lowest flowers of the same axis, showing secondary phloem in process of differentiation into sieve-tubes and companion cells. 3. A mature bundle, from the flowering region of an axis gathered on May 28 , in which cambial activity has practically ceased. $c b$, cambium; $p h$, phloem; $p$ ph, protophloem ; $p x$, protoxylem. $\times 275$.

terminal bud in February, cambium was recognized, but the most favourable time for observing it seemed to be at the end of April or the beginning of May, when many of the axes exceeded half a metre in height. Fig. I shows a bundle from the flowering region of an inflorescence gathered on May 7. Here cells of a meristematic appearance, arranged in radial rows, intervene between the xylem and phloem, while the phloem is not yet differentiated into companion cells and sieve-tubes. In bundles from 
another inflorescence axis, gathered on April 27, as many as ten undifferentiated elements have been traced in a single radial row. In Fig. 2 a bundle is represented from a lower level in the axis gathered on May 7 . Cambial activity is still in progress, but part of the secondary phloem has become modified into large sieve-tubes and small companion cells, thus somewhat obliterating the radial arrangement. Fig. 3 shows a bundle from the flowering region of an older inflorescence, gathered on May 28. Here cambial activity seems to have completely, or almost completely ceased. In these figures it will be observed that little or no secondary xylem is formed; the cambium seems to confine its activities, mainly if not entirely, to the production of secondary phloem. The same peculiarity has already been recorded for other members of the Liliaceae by Andersson.

Meristematic activity is not rigidly restricted to a single layer of initial cells. Dividing nuclei seem most frequently to occur near the innermost or xylem end of the radial files; they have been noticed in different cases in the first, second, third, fourth and sixth cells, counting from the inner end. In one case nuclei were seen dividing simultaneously in the fourth and sixth cells of the same file, and, in another case, in the first and third.

In addition to Eremurus, a few other genera among the Liliaceae have been examined. In the case of shoots of Asparagus officinalis, L., at the stage at which they are gathered for market, an ephemeral cambium was detected in the apical region. In such a shoot, gathered on May I, transverse sections across the 'head', at a distance of $\mathrm{I} \mathrm{cm}$. from the apex, showed the metaphloem to consist of radial rows of undifferentiated cells, uniformly filled with cytoplasm. Traces of the same arrangement were visible at the base of the 'head', but, $2.5 \mathrm{~cm}$. lower, the differentiation into sieve-tubes and companion cells had completely masked all indications of radial grouping.

Distinct traces of cambium have also been observed in a young inflorescence axis of Nothoscordum fragrans, Kunth, gathered on May 18. The bundles are more or less $\mathrm{Y}$-shaped, and the cambium follows a curved line.

In the young inflorescence axis of Hemerocallis fulva, L., cambium has also been recognized. Russow, ${ }^{1}$ as has already been mentioned, noted more than forty years ago the occurrence of cambium in another species, $H$. flava, L., so the present observation merely confirms its existence in this genus.

\section{SumMary.}

In this paper the literature on intrafascicular cambium in Monocotyledons is briefly reviewed, and it is recorded that, in addition to the cases 
already known, cambial activity occurs in the bundles of the young inflorescence axes of Eremurus himalaicus, Baker, and Nothoscordum fragrans, Kunth, while an ephemeral cambium occurs in the young shoots of Asparagus officinalis, $\mathrm{L}$. The fact that cambial activity in Monocotyledons is, actually, more widespread than is generally assumed, offers a slight additional confirmation of the view, already expressed by Anderson, Queva, Chrysler, and Sargant, that the existence of this vestigial, intrafascicular cambium indicates that Monocotyledons have been derived from a dicotyledonous stock.

\section{LITERATURE.}

ANDERSSON, S. (1888): Om de primära kärlsträngarnes utveckling hos monokotyledonerna. Bihang till k. Svenska Vet.-Akad. Handlingar, Bd. xiii, 1888, Afd. III, No. I2, 23 pp., 2 pl. (Abstracted Bot. Centralblatt, vol. xxxviii, pp. $586,5^{87}$, and 61 8, 619, I889).

Chrysler, M. A. (1906): The Nodes of Grasses. Bot. Gaz., vol. xli, 1906, pp. I-16, 2 pl.

Godfrin, J. (1884): Recherches sur l'anatomie comparée des cotylédons et de l'albumen. Ann. d. Sci. nat., Bot., sér. vi, t. xix, I884, pp. 5-1 $5^{8}, 6$ pl.

Gravis, A. (1898): Recherches anatomiques et physiologiques sur le Tradescantia virginica, L. Mémoires couronnés et Mém. des savants étr. Acad. Roy. des Sci., des lettres et des beaux-arts de Belgique, t. 1vii, I898, 304 pp., $27 \mathrm{pl}$.

Hil., T. G. (1900) : The Structure and Development of Triglochin maritimum, L. Ann. of Bot., vol. xiv, 1900, pp. $83-107,2$ pl.

Möвıus, M. (1886): Untersuchungen über die Stammanatomie einiger einheimischer Orchideen. Ber. d. deutsch. Bot. Ges., Bd. iv, I886, pp. 284-92, I pl.

Plowman, A. B. (1906): The Comparative Anatomy and Phylogeny of the Cyperaceae. Ann. of Bot., vol. $\mathrm{xx}, 1906, \mathrm{pp} . \mathrm{I}-33,2$ pl., 2 text-figs.

Queva, C. (1899): Contributions à l'anatomie des Monocotylédonées. I. Les Uvulariées tubéreuses. Travaux et Mémoires de l'Université de Lille, t. vii, I899, Mém. No. 22, 162 pp., II pl.

Russow, E. (1875): Betrachtungen über das Leitbündel- und Grundgewebe (Jubiläumschrift Dr. Alexander von Bunge), 78 pp., Dorpat, 1875 .

Sargant, E. (1908). The Reconstruction of a Race of Primitive Angiosperms. Ann. of Bot., vol. xxii, 1908, pp. 121-186, 2 I text-figs. 


\section{$2 \mathrm{BHL}$ Biodiversity Heritage Library}

Arber, Agnes Robertson. 1917. "On the occurrence of intrafascicular cambium in monocotyledons." Annals of botany 31, 41-45. https://doi.org/10.1093/oxfordjournals.aob.a089634.

View This Item Online: https://www.biodiversitylibrary.org/item/232813

DOI: https://doi.org/10.1093/oxfordjournals.aob.a089634

Permalink: https://www.biodiversitylibrary.org/partpdf/320173

\section{Holding Institution}

Smithsonian Libraries

\section{Sponsored by}

Biodiversity Heritage Library

\section{Copyright \& Reuse}

Copyright Status: Not in copyright. The BHL knows of no copyright restrictions on this item.

This document was created from content at the Biodiversity Heritage Library, the world's largest open access digital library for biodiversity literature and archives. Visit BHL at https://www.biodiversitylibrary.org. 